\title{
Toward justice and social transformation? Appealing to the tradition against the tradition
}

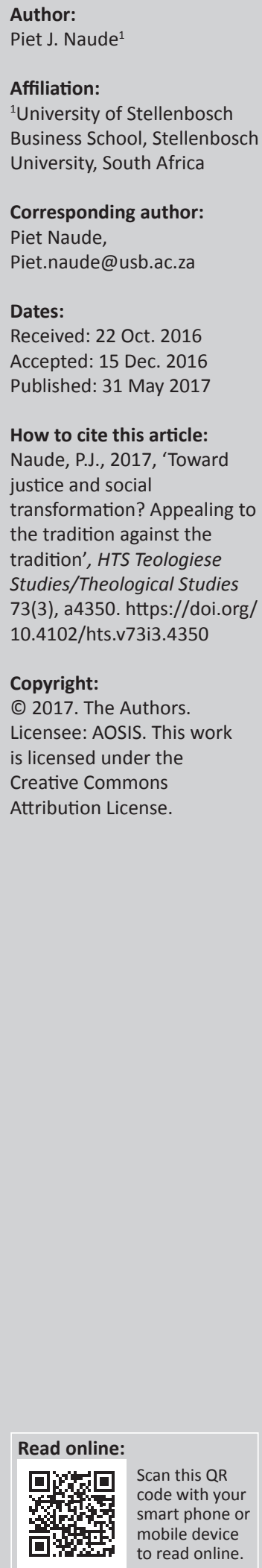

This article starts with a brief statement on the well-known contradictory nature of the Reformed tradition in South Africa, defending injustice and struggling for justice in the name of the same tradition. By following the work of Reformed systematic theologian D.J. Smit, it argues that the justice-affirming potential of the Reformed tradition is a hermeneutical task built on three specific re-interpretations: (1) the reinterpretation of Scripture from the perspective of the weak, the poor and the oppressed (against a hermeneutic of creation orders and God-willed division of people) (2) a rereading of John Calvin to affirm the dignity and freedom of all humans (against the grain of neo-Calvinist interpretations) (3) a rereading of Karl Barth with a focus on God's inclusive grace, Christian confessions and the nature of the Christian life (against the limitation of his influence because of his perceived actualistic view on Scripture or unscientific, foundational methodology). The article closes with a brief look into the agenda for social transformation faced by us in the second decade of the 21st century, and under what conditions the Reformed faith will be able to make an enduring contribution to public life in (South) Africa.

\section{Introduction}

Those of us who have been writing and doing theology in South Africa over the last three decades know that the Christian gospel - as interpreted from a Protestant or more specific Reformed tradition - can simultaneously be used as a powerful force against social transformation and as a positive force for justice and the transformation of society. This ambiguity and the historicaltheological trajectory it took have been the subject of countless academic studies and reflections, ${ }^{1}$ and need not to be recounted here.

We now approach 2017 and the festive commemoration of the Protestant Reformation that commenced in the 'protestation' of Martin Luther against what he judged as theological heresies and misuse of religious power by the then Roman Catholic Church. Looking back, the very birth of this tradition, reflected in its name ('protesters'), was to confront the realities of church, politics, economics and broader society from convictions rooted in Scripture. Again, the socialtransformative trajectory of the Reformation with its very many faces and without which the history of Western Europe after the 16th century is not to be conceived has been outlined and will be in these days once again a key topic of our commemorations.

This article has a quite limited focus. It asks the question as to what the conditions are for the Reformed tradition to be a positive force for social transformation and justice. The answer is drawn from interpretation: It all depends on how Scripture and the main proponents of the Reformed tradition are read. This sounds deceptively simple. It is in fact a much more complex matter because - as we know from the history of interpretation and the specific hermeneutical and exegetical controversies in South Africa during the church struggle of the 20th century - there are competing paradigms from which meaning is constructed. There are different readers; there are different texts and there are different contexts.

To illustrate this struggle of interpretation, this article will recount the way in which one South African Reformed theologian, Dirk (D.J.) Smit, has approached the reading of Scripture and the appropriation of John Calvin and Karl Barth. Calvin and Barth are generally acknowledged as key figures in the development of Reformed thinking. Anyone who has read Smit's extensive oeuvre will know that it would be impossible to do full justice to his wide, informative and complex

1.A classic remains De Gruchy's (updated) overview of the church struggle in South Africa (De Gruchy 2004). For a condensed theological overview, read Naudé (2011:23-48). 
writings on these topics, which includes the complexity of talking about ' $a$ ' Reformed tradition in general and in particular in South Africa. ${ }^{2}$ My decision therefore was to undertake a close reading of a few essays as illustration of Smit's specific contribution to interpret the Reformed tradition in such a manner that its social transformative power could be (re)vitalised.

There are different layers represented here: The first layer refers to the Scripture passages as read by Smit in conversation with biblical scholarship as well as the primary sources stemming from Calvin and Barth. The second layer may be seen as the extensive network of secondary sources so typical of Smit's writing style. And then, as a third layer, there are Smit's own views developed in conversation with these sources. My reading functions 'on the surface' of the third layer, taking Smit's readings as reference point, and then complementing these with interpretative remarks of my own, which may be seen as a fourth layer of interpretation. The aim is not to do a critical appraisal of Smit's readings but to represent them fairly in service of the overarching purpose of this article: How could the Reformed tradition 'work' for social transformation?

\section{Christian ethics an ethics-of-seeing}

I start with 'On learning to see? A Reformed perspective on the church and the poor' (Smit 2009c), a paper read during the fifth biennial meeting of the International Academy of Practical Theology in Stellenbosch (April 2001), and published in 2003. I read the version as included in Essays on being Reformed, Collected essays 3 (Smit 2009a:473-492).

Smit introduces his paper with reference to the endemic poverty in Africa and South Africa, referring both to statistical and narrative examples. The narratives give 'a face' to poverty and he quotes an anonymous poem from the Cape Flats:

Elsiesrivier, geboorteplek van my,

Kyk en sien hoe al jou mense ly. ${ }^{3}$

Drawing on the second line of this short poem ('look and see ...'), he proposes that an appropriate starting point for Christian ethics is the act of seeing (2009c:476). He draws specifically on the well-known decision-making model developed by Heinz Eduard Tôdt that starts with the aspect of seeing the problem. There can be no moral question unless the problem is perceived. Seeing itself has three different dimensions, 'namely perceiving the problem, accepting it as a moral challenge, understanding, interpreting it in a preliminary way' (2009c:476, [original emphasis]).

This act of seeing is consequently itself filled with ethical questions: In the topic under discussion - poverty - it is possible that poverty and poor people are not even seen

2.See Smit (1992) and the frequent references throughout his work to the manysidedness of the Reformed trajectory in South Africa.

3. Roughly translated: 'Elsies River, place of my birth; look and see how all your people suffer'. in the first place. This may be due to social blindness, ideological presuppositions or geographical distance intensified by, for example, apartheid spatial planning. It is further possible to indeed see 'poverty' but not framing it as a moral challenge. 'This is how things are. We will always have the poor with us. Inequality is a necessary consequence of economic growth', some might say. Or it is possible that the problem is recognised and constructed as a moral issue, but that 'we fail to understand, interpret it correctly, for what it truly is, because we fail to fathom what is really at stake' (2009c:477).

What is at stake in this act of seeing is not just a superficial or partial moral blindness but the very identity of the church, the very impact of the gospel and our very integrity as Christians itself. Smit (2009c) asks rhetorically:

Could it be that what is at stake is indeed more than mere ethics ... but faith itself, ecclesiology itself, the gospel itself? Could it be that (in facing poverty, PJN) we are faced with the unseen, yes, the Unseen One, with Jesus Christ Himself? (p. 486)

This latter remark stems from the tradition of Matthew 25 that we meet Christ in those who suffer. And then the first question is not how we can solve the problem (of alleviating or eradicating poverty), but we are confronted with the much more fundamental question on how we could suffer with those who cry, how we could show com-passion' (2009c:487, [original emphasis]). In short, Smit remarks: '... we are called to compassion, not to solve problems' (2009c:488). Counting on Catholic scholar, J.B. Metz, and the work of feminist scholar, Sharon Welch, Smit observes that it is a bitter fruit of modernity that we omit suffering and compassion from our ethical deliberation in favour of an ethics-of-control, thereby ending in despair (because of seemingly insurmountable global problems) and without moral imagination (because we are trapped in a culture of problem-solving). ${ }^{4}$

This failure to see and to embrace co-suffering is at the root of the indifference to the many social and ethical problems facing us. In our age of information over-load - including images and information of suffering around the globe and in our own back-yard - we simply shut ourselves off, migrate inward, shrug our shoulders and we 'could not care less'. ${ }^{5} \mathrm{We}$ either do not care because we do not see, or we do not see because we do not care (Smit 2009c:491).

The implication is that (Smit 2009c):

we are not challenged, in the first place, to solve the problems of the suffering and the poor, but to relate to the many faces we see all around us, to recognise that we are related to them, part of them, part of the suffering, that we are implicated in so many ways in the stories of their suffering, that our stories are integrally part of their stories, and the story of Jesus Christ, and the church, and our faith, of our identity and our integrity, therefore as well, even and especially when we fail to see. (p. 488)

4. Read Smit (2009c:487-488), and see footnotes 29 and 31 for reference to origina sources.

5.Smit (2009c:491). For a reference to S Dennis Ford, see Smit (2009c:footnote 38). 
This raises the crucial question: Can we learn to see? If so, how can a church - even a whole tradition like Protestantism with its failure to adequately see the suffering of others ${ }^{6}-$ learn to see?

At this point Smit returns to the roots of the Protestant and Reformed tradition: Seeing depends on hearing the Word of God. 'In fact, hearing is a form of seeing', (2009c:486) Smit writes in his comment on the opening paragraphs of Calvin's Institutes. ${ }^{7}$ It is through reading, preaching and worshipping the Scriptures that we learn to see. This occurs in all the different concrete manifestations of being church from individual believers to the ecumenical church (Smit 2009c:489-490), assisting the Protestant tradition to avoid forms of docetic ecclesiology and talking about the church in doctrinal formulations without concrete reference points. ${ }^{8}$

But from which vantage point shall we learn to see and to read and to hear? To answer this question, Smit makes two important observations.

Firstly, if we are to meet others via compassion in their suffering, is it not true that we should therefore learn from them about suffering and poverty?

Could it perhaps be true that the suffering of this world, particularly as seen from the perspective of the poor of Africa, confronts the church with more than an ethical challenge ... more than statistics, causes and results that can be ... described empirically? (Smit 2009c:485-496, [author's own italics])

Secondly, in an essay 'Wat beteken "Gereformeerd?"', 9 Smit (2013c) emphasises that it is typical of the Reformed life-style to be living in the world before the face of God. God is present in the Scriptures, believed as the Word of God:

The life coram Deo is a life coram Dei loquendi, before the face of the speaking God; it is a life ex auditu Verbi, a life from the continuous hearing of the Words of God. (Smit 2013c:24, [author's own italics])

That is why the reading and preaching and praying of the Word is so central to the Reformed liturgy.

To ensure what Smit calls a 'responsible theological hermeneutic' (Smit 2013d:52), this Word should not be read alone only. It is a reading with others. Who are these 'others'? These others may be the local congregation as the primary locus of reading and hearing in the liturgy. But we are also held accountable by the fathers and mothers of our tradition, representing the readings of Scripture through the ages. Then there are the important controls derived from Biblical sciences, providing us with the literary, historical and rhetorical knowledge to read the Bible responsibly. To these

6.See the interpretation of Barth below.

7.See Smit (2009c:486, footnote 27).

8.See references to H.R. Niebuhr, J. Gustafson and D. Bonhoeffer on page 498 of Smit (2009c).

9.'What does "Reformed" mean?' was first published in Afrikaans in 1998 and later as chapter 2 in Opstelle oor Gereformeerd-wees vandag. Versamelde opstelle 4 (edited by Len Hansen in 2013, 21-31). It is referred to as Smit (2013c). must be added the voices of the ecumenical church, so that we read with Christians from other traditions and from other contexts.

Then Smit (2013d) makes a significant addition to our circle of reading-partners:

In the listening to each other and one another, a very special place must be assigned to those who were in the past normally excluded, or perhaps still are, to say in the church what the Word of God do to them and what they hear and see in the Word. Often they are the best enabled to assist us in coming to know ourselves ... Precisely in this case, the witnesses, the experiences and the insights of the excluded, may assist us further. (p. 55, [author's own translation, original emphasis])

These two points taken together imply that for Smit the key to retrieving and revitalising the socially transformative power of the Reformed tradition - and for that matter the gospel, the Christian life and the church - lies in compassion with the poor, seeing suffering from their perspective, and reading the Scriptures with the excluded, hearing them to understand both God and ourselves better.

This conclusion requires further explanation: Smit is not advocating compassion with those who suffer, and coreading with the poor, as a mere sociological means to a better understanding and seeing of the situation. That may well be the case. No, these are theological imperatives. Furthermore, Smit is not according the suffering and the poor an exclusive epistemological status as in some liberation theologies. The poor and marginalised nevertheless occupy 'a special place' amongst those who journey with us in seeing the will of God in the world today. ${ }^{10}$

It is this hermeneutical key - the theological conviction in Smit's work - that informed the formulation of the Belhar Confession. This confession includes under the article on compassionate justice that (Smit 2009c):

God has revealed himself as the one who wishes to bring about justice and true peace among people; that in a world full of injustice and enmity he is in a special way the God of the destitute, the poor and the wronged, and that he calls his church to follow him in this ... (p. 480)

The special place of the destitute and the poor does therefore not derive from their socio-economic position, but from the manner of God's own revelation.

Rereading the Scriptures ... Let us now see this hermeneutic at work in Smit's reading of the Book of James in an essay called 'Oor Jakobus en die Belydenis van Belhar'. ${ }^{11}$ This essay is less known than his powerful explanation and defence of Belhar's article on justice originally published in A moment of

10.I make this point because one of the strongest rhetorical criticisms of the Bellhar and Naudé (1998), as well as Naudé (2011:139-142).

11.First published in German (1998) and later included in Afrikaans as chapter 15 (211-227) in the fourth collection of Smit's essays in 2013, referred to here as Smit (2013b) 
truth which he edited with Daan Cloete. ${ }^{12}$ This essay on James - originally a series of Bible studies in conjunction with Smit's exposition of the Belhar Confession itself ${ }^{13}$ - does serve as example of what was said in the introduction: The social transformative power of the Reformed tradition lies in the manner in which the Scriptures are read.

Smit commences his reading with the observation that contrary to those who suggest that the book of James is merely a loose connection of wise counsel - James in fact addresses a church in conflict with one another and in themselves (Smit 2013b:212, see James 1:4). At the root of these conflicts lies the tension between hearing and doing, believing and acting. In order to assist this conflict-ridden congregation, James holds up different mirrors in the hope that they will see themselves as they really are. Smit then reconstructs his reading of the book along three main themes as reflected in the Belhar Confession.

Firstly, the church lacks a lived unity because they discriminate against people according to external measures like what they wear and how rich or poor they are. This is a form of selective love of the neighbour; this is living not in accordance with the law but applying double standards; this contradicts the very nature of God who exactly chooses those whom the world counts as poor, insignificant and foolish; this is dangerous as they will be judged by God with the measures they apply, not receiving mercy in the end if they do not show mercy. This discrimination breaks up the unity of the church.

Secondly, there can be no true reconciliation due to the misuse of the tongue, because of the way they speak about each other. Keeping the tongue in check is a sign of true religion (James 1:26); if not, such religion is worthless. Our discrimination and choosing sides (normally with the rich) is expressed in our words. This already contradicts our faith and leads to internal conflict and turmoil. But more than this: misuse of the tongue, using it as a dangerous fire or deadly poison (James 3), is itself in conflict with our deepest convictions. How is it then that the same tongue that worships God is used to curse others? (James 3:10) We curse others, says Smit, through direct, but mostly indirect and subtle means: we generalise and write them off ('they are all like this'); we classify people in our minds and then talk about them via our ideologies and pre-judged ideas, reinforcing caricatures about them. 'The tongue is the instrument with which we hit, wound and kill each other' (Smit 2013b:219, [author's own translation]). Our speaking is the sign of our lack of reconciliation.

12.See Cloete and Smit (1984:53-65, 127-150). The Afrikaans version was published in ' $n$ Oomblik van waarheid (Cape Town: Tafelberg), pp. 62-75, 143-159 and was later included in Geloof en openbare lewe. Versamelde opstelle 2 as chapter 16 277-304 (Smit 2008a). References are to this anthology, and specific attention is drawn to the extensive footnote 14 (2008b:294-297) where Smit argues for the formulation on justice from the book of James. Smit also made significant contributions to preaching guidelines from the book of James in the well-known Woord teen tie preachies guidelines from the book of James in the well-known Woord teen die Lig-series. Read his commentaries on James in Riglyne vir prediking oor die wandel met God. Woord teen die lig IIII/2, red B A Müller, C.W.Burger, D.J.
Smit (Kaapstad: NGKU), 1991.

13.Also published in German (1998) and later included in Afrikaans as chapter 10 (129-153) in the fourth collection of Smit's essays in 2013, referred to here as Smit (2013a).
But what is the deepest reason for this conflict, this wounding of the other? James replies with great clarity: The struggle and fights arise from selfish yearnings that battle within us (James 4:1). We covet and then cannot get, 'so you quarrel and fight' (4:2). We even use our religion and prayer to fulfil our selfish desires, but behind enmity lies the promotion and retention - against all odds - of our own interests.

Thirdly, there is conflict because there is no caring justice amongst the Christians due to the lack of sensitivity for the plight of the poor. Smit points out that in the Biblical traditions there is a close connection between peace, reconciliation and justice. Conversely, conflict and lack of peace arises from injustice.

There is a clear tension between rich and poor in this letter. It runs like a thread through everything that James writes: The rich should take pride in their humility 'since they will pass away like a wild flower' (James 1:10, NIV). Pure and faultless religion is to care for orphans and widows in their distress (1:27). Favouritism toward the rich and dishonouring the poor is against the very nature of God (3:1-10). James' letter ends with a stern warning to the rich who underpay their workers, described as innocent people who were murdered and slaughtered (5:6). Rich people must 'weep and wail because of the misery that is coming on you' (5:1).

How can this enduring and multi-faceted conflict be addressed? The last part of James' letter provides the guide: by praying and the confessing of sins. Smit notes that the whole book could be seen as an instruction in prayer. James calls to prayer for wisdom at the beginning; he warns against prayers with selfish motives in the middle; and he ends with a call that conflict can only be resolved with common prayer. This common prayer is prayer over each other's' sins, so that forgiveness, restoration, unity and peace could be restored (5:13-16). There is, what Smit calls 'a solidarity in guilt' because all stand before all and should honestly confess their sins to one another, 'so that you may be healed' (James 5:16). ${ }^{14}$

Seeing that the Reformed tradition was built on the return to the Scriptures as key source of God's revelation (sola Sciptura), and seeing that its motto is to be continually reforming (semper reformanda) according to God's Word, the transformative power of this tradition stands or falls with the interpretive task of reading the Scriptures anew for every age and context.

In the specific historical epoch of the early 1980s in which Smit read the book of James (and many other passages!), the dominant hermeneutical tradition in Reformed circles still took 'pluriformity' guiding the 'order of creation' as the primary lens through which to interpret the Bible and social

14.This reminds of the moving excerpts from the accompanying letter to the Beina confession where the confessing church says: 'We speak pleadingly rather than accusingly' and we know that the attitudes and conduct that work against the gospel are present in all of us. It is certainly not intended as an act of selfgospel are present in all of us. It is certainly not intended as an act of self-
justification and intolerance, for that would disqualify us in the very act of preaching to others. See Naudé (2011:102) for a discussion. 
realities. ${ }^{15}$ The task for Reformers - throughout history - was to read against the grain of ruling ideologies, and to constantly be reminded of the corrective and instructional power of the Word of God before which we all always stand in awe and judgment. In this sense, the Belhar Confession was a hermeneutical act against a reading of the Scriptures that up to that point justified schism, conflict and injustice in the name of God. The lenses of pluriformity and creation orders were replaced by the key lenses of Trinitarian theology, Christian unity, reconciliation in the face of diversity, justice for the weak and the call to be obedient to the Lordship of Christ, irrespective of the orders of the day.

The question now arises: Would this 'ethics of seeing' and this specific hermeneutical approach find theological affirmation in the work of Calvin and Barth, recognised as the main proponents of Reformed thinking?

Let us then turn to a few aspects of Smit's reading of Calvin and Barth. In line with the starting point, only a fraction of Smit's extensive writings on both these giants in the Reformed tradition is represented here, and in no way represents the rich variety of perspectives brought via a reading of both the original sources and engagement with vast secondary scholarship.

\section{On Karl Barth: Learning to see suffering people as human beings}

In the context of the argument in this chapter, two essays by Smit on Barth are of particular importance: "“... The doing of the little righteousness" - On justice in Barth's view on the Christian life' ${ }^{\prime 16}$ and the earlier 'Paradigms of radical grace' ${ }^{\prime}{ }^{17}$

One could argue that this latter essay by Smit provides the theological mirror image of the exegetical work done a few years earlier in his essay on the God of the destitute and the poor (see Smit 1984a). For this theological rationale, Smit turns to Barth's doctrine of reconciliation (CD/IV) and specifically his exposition of Jesus as the royal man (CD $\mathrm{IV} / 2$ ) who performs miracles that are seen as 'paradigms' of the kingdom of God. This kingdom is marked by God's radical grace which liberates unconditionally from the destructive powers of evil.

Following Barth, Smit first states that Jesus, the royal man, exists analogously to the mode of God's existence (1988:23). The royal man - through his humiliation - shares fully in the destiny of humankind. Almost to the point of prejudice the royal man shows remarkable affinity for the weak, the lowly and those who are poor in moral, economic spiritual and

15.See how this dominant hermeneutic is at work in the DRC's study document Ras volk en nasie: Volkereverhouding in die lig van die Skrif (1974), and see Naude (2012) for a discussion on how this angle of reading is still present, though in lesse form, in Kerk en samelewing (Ned Geref Kerk 1986) which replaced the 1974 views.

16.First published in 2004 and later included as chapter 20 (pp. 359-378) in Essays in public theology. Collected essays I (2007). References are to the 2007 version, indicated as Smit (2007a).

17.First published in 1988 in On Reading Karl Barth in South Africa, edited by Charles Villa-Vicencio, 17-44. I will draw on the discussion of this essay in an overview of Barth-reception in South Africa, published as Naudé (2013). social terms. This affinity is not based on any merit that might lie in the situation of the poor or in poor people themselves love flows only because of God's infinite grace. The royal man thus affirms and reflects the divine yes to humanity, especially humanity in suffering. The cross can therefore be viewed as the triumph and coronation of the royal man (Smit 1988:25-27).

The miracles of Jesus, the royal man, are done toward those 'with whom things are going badly;' for whom human life is 'like a great hospital' (Smit 1988:29). Their suffering is mostly physical and the focus of the miracles is not primarily salvation from sin, but releasing from suffering, irrespective of their sin. This is a powerful demonstration of God's interest in humankind itself; in humans as cosmic beings, created by God. In the miracles, God is placed on the side of humanity and against hostile powers, nothingness, evil, and destruction that cause suffering and death (Smit 1988:31-32).

An interesting question now arises: Why did Protestantism miss this point? Barth's answer - affirmed by Smit (1988:33) is that the message of the gospels was understood from the side of humanity where sin and need for forgiveness were seen as almost 'meritorious' grounds for God's action. In contrast to this, the message must be understood from the view of the kingdom, that is from God's unconditional free grace towards humanity, not only understood as sinners, but as God's creatures in need of total redemption.

The 'option for the poor' is therefore not a simple ethical matter or socio-economic description of a specific class of people - it is a deeply theological matter, steeped in the doctrine of reconciliation, because in this option we see 'the astonishing light' of God's radical, free grace. 'We can now conclude', writes Smit in line with his 1988 exegetical view, 'that Reformed Protestantism finds in Karl Barth an important witness to testify that the God of Jesus Christ is indeed in a special way the God of the poor' (Smit 1988:42). ${ }^{18}$

This understanding of the miracles from the perspective of God's kingdom must be read in conjunction with the very last writings of Barth on the coming of the kingdom in the Lord's prayer as discussed by Smit (2007b) in '... The doing of the little righteousness'.

Typical of Barth, he emphasises that the justice of God's kingdom as revealed in the covenant of Jesus Christ is a superior justice to anything that human beings can contemplate or accomplish. But insofar as Christians pray for the coming of kingdom:

they act in accordance with their prayer as people who are responsible for the rule of human righteousness, that is, for the preservation and renewal, the deepening and extending, of the

18.This conclusion on reading Barth is remarkable if seen in the context of the Barth reception in the dominant Afrikaans Reformed circles at that time. For an overview and discussion of different Barth receptions, read Naudé (2013), and note the manner in which particularly F.J.M. Potgieter succeeded in sidelining Barth from manner in which particularly F.J.M. Potgieter succeeded in sidelining Barth from the early 1960 s onward by framing him as deviating from the Reform
on key issues like church unity, baptism and the authority of Scripture. 
divinely ordained safeguards of human rights, human freedom, and human peace on earth. ${ }^{19}$

There is therefore a necessary and intrinsic correspondence between invocation of God to let his kingdom come and obedient human action to rise up for righteousness, fighting the lord-less powers and addressing the plight of humanity estranged from God, from themselves and from others (Smit 2007a:363)..$^{20}$

Human beings cannot bring in the kingdom of God. As an eschatological act that has already taken place in the definitive event of righteousness in Jesus Christ, praying is in fact the first and most powerful ethical act for humans as they are necessarily caught up by what they pray, and then accept responsibility in freedom 'for the doing of the little righteousness' (quotation from Barth, Smit 2007a:367). ${ }^{21}$

In line with the reading of the miracles, and in line with an 'ethics of seeing', 22 Christians learn to see people as human beings - 'and therefore never as causes, as members of this or that, not even as Christians or non-Christians, as good or bad' (Smit 2007a:370). Christians learn to see people 'in the way the living God - in Christ and through the Spirit - sees them'. Christians especially see human beings in need, bringing hope to the hopeless, bringing courage to the discouraged, by 'taking little steps' in improving their lot (Smit 2007a:371). The relativity of our striving for human righteousness - 'our response is only one of witness' - in no way diminishes our responsibility to simultaneously call for divine righteousness in the sure knowledge that the Son of Righteousness will shine upon us in our human struggle for justice (Smit 2007a:374).

\section{On John Calvin: The pathos of God and human freedom}

In his essay, 'Freedom in belonging? John Calvin's understanding of human freedom', Smit (2009b:121-140) reminds us that Calvin discusses human freedom in Book III.19 of the final edition (1559) of the Christian Institutes and this discussion forms an integral part of Calvin's description of the Christian life. The key to Calvin's understanding of the Christian life is that 'we are not own', ${ }^{23}$ that is the conviction that we do not belong to ourselves, but to God in Jesus Christ 19.Barth in The Christian life (1981:205), as discussed by Smit (2007a:362).

20.In a perceptive footnote 31 (p. 374), Smit (2007a) dispels the notion that the socalled early Barth of the Römerbrief (1918) denied all human freedom and the called early Barth of the Romerbrief (1918) denied all human freedom and the importance of human conduct if compared with Barth's later work stemming from 1962. If one accepts that human conduct is a token or parable of God's action - as Barth suggests - there remains a qualitative difference between God and human action, but it does not at all diminish the importance of human conduct in particular.

21.For an in-depth analysis of prayer in Barth's theology, read Van Zyl (2013). After establishing prayer as the central 'access point' to Barth's theology, the relation between faith and obedience (chapter 2), faith and prayer (chapter 3 ) obedience and prayer (chapter 4) and then the close inter-relations amongst faith, obedience and prayer are set out in chapter 5 , followed by a conclusion about prayer as the chief exercise of faith.

22.See Smit's discussion on the role of 'seeing' in Barth's understanding of the Christian life (Smit 1997).

23. Read the passionate plea around the theme of 'we are not our own' and 'we are God's' in the Institutes book III.7.1 as discussed by Smit (2009b:124). through the Spirit. But belonging to God simultaneously means that we belong to one another. 'The glory of God depends on how we practise this mutual belonging, unity, solidarity, interconnectedness, sharing with one another' (2009b:125).

In his 'Views on Calvin's ethics from a South African perspective', Smit (2009d) then draws on Nicolas Wolterstorff's description (1987) of how Calvin understands the pathos of God. This pathos, revealed in Jesus Christ, should guide us in our belonging to one another. Contrary to a theological tradition going back to Augustine in which God is pictured in 'blissful apathy', Calvin revives the Biblical tradition of people bearing the image of God. The consequence is that when we inflict injury or injustice on a fellow human being, we are wounding God himself. ${ }^{24}$ God is suffering in human suffering and 'to pursue justice is to relieve God's suffering' (Wolterstorff 1987:17-18, see Smit 2009d:23).

In a powerful passage from Book III.7, Calvin calls on Christians to do good to all others, without exception. Calvin understands that we usually accord our assistance to others based on our estimation of their worthiness in our eyes. He then warns:

But Scripture subjoins a most excellent reason, when it tells us that we are not to look at what people in themselves deserve, but to attend to the image of God, which exists in all, and to which we owe all honour and love. (as quoted by Smit 2009d:24, [author's own italics])

Who are then included in our love and justice?

Calvin - with careful rhetoric - enumerates: A stranger. A person that is mean and of no consideration. Someone to whom we owe no duty. A person who not only merits no good, but in fact has 'provoked you by injury and mischief'. Those who hate us. Those who curse us. All the while:

we are not to reflect on the wickedness of people, but to look to the image of God in them, an image which, covering and obliterating their faults, should by its beauty and dignity allure us to love and embrace them. (Institutes III.7.6; see Smit 2009d:24-25)

In a context where Calvin's own voice was drowned out by his reception via neo-Calvinism - especially via a specific reading of Abraham Kuyper - the question arises whether and how one could draw on Calvin to assist in escaping from an ideological support for (racial) disunity and selective justice? Can we call on Calvin to regain a critical consciousness toward our being trapped in the power of exclusive culture and separated peoples, exactly upheld in the name of Calvinism?

This is where Smit's discussion of three aspects of human freedom ${ }^{25}$ in Calvin is so important: The first aspect relates to individual freedom, the freedom of conscience that arises

24. See Wolterstorff's reference to Calvin's commentary on Genesis 9:5-6, where Calvin speaks about the image of God engraved on all people. 'This doctrine is to be carefully observed, that no one can be injurious to their brother or sister, without wounding God himself (see Smit 2009d:23, [author's own italics]).

25.As usual, Smit frames his discussion in this essay (2009a) with wide references to secondary literature. In this case, he specifically follows Stevenson (1999). 
from receiving assurance of justification before God; this is the freedom of being saved by grace alone (Smit 2009b:129). The second aspect relates to the communal freedom to serve God and perform duties of love toward others and to social institutions. Freed from the yoke of the law, one willingly obeys God's will in practising piety by serving the material and spiritual interests of others (p. 131). The third aspect - the most revolutionary form of freedom - relates to historical freedom, i.e. the freedom to be indifferent to the power and influence of cultural, tradition, and religious obligations (pp. 133-135).

These freedoms are already remarkable in themselves. But what should be noted is the self-critical tensions which accompany them:

Yes, the individual conscience is indeed free and is the basis of all freedom. But this freedom is never individualistic, because human partiality and finitude requires a moral order that transcends and completes the individual freedom.

The freedom to serve in the social orders of the day constitutes forms of social involvement under prophetic judgment and under self-critical limitation. Christians respond to God's calling in all spheres of life, but are continuously aware of the limitations and flaws of whatever corporate action may achieve. Christians act and hesitate at the same time (Smit 2009b:132).

Similarly, Christians are emancipated from whatever duties and obligations culture and other temporary social orders require. The authority of culture and tradition is radically undermined. But at the same time, God's revelation and grace takes on historical and cultural forms and Christians need to steer between either a debasement or an idolisation of history (Smit 2009b:137).

One could now interpret these freedoms as the 'response' of Calvin to the neo-Calvinism that held sway in dominant Reformed theology for the greater part of the late 19th century and the first half of the 20th century in South Africa. ${ }^{26}$ This is, inter alia, what it means to reclaim the Reformed tradition by appealing to the tradition, showing that it has been miss-represented and that its deepest thrust has been lost. ${ }^{27}$ This is liberating Reformed theology. ${ }^{28}$ This is choosing the true face of Calvin. ${ }^{29}$ The sectarian self-defence against the voice of the ecumenical church stands in opposition to Calvin's notion of self-transcending and communal freedom. The apathetic attitude to those who were marginalised and excluded, stands in opposition to the pathos of God and the call to love all others without exception, because they carry the image of God. But most of all, the self-assurance and

26.For a short description of this neo-Calvinism, read Smit (2002).

27.An excellent example of reclaiming Calvinism by drawing on Calvin, is contained in Boesak (1984).

28.John de Gruchy's title (1991) and well-known study has the double meaning of a Reformed theology that liberates and that stands in need of liberation.

29.See Naudé's (2009) two part essays on 'The two faces of Calvin in South Africa: In honour of the 500th commemoration of John Calvin's birth'. arrogance, the rigid refusal to change - deepened by a pious self-believe and backed by political power - stand in opposition to the prophetic, self-critical strand that Calvin weaves through all his discussions of human freedom.

Smit rightfully concludes: Calvin's notion of belonging in which the threefold freedoms are embodied, call:

for forms of community in which the realities of exclusion, marginalisation, alienation, and oppression are continuously opposed and hopefully overcome. It calls for qualitative forms of community, community of radical bridging, visible in actual liberation, living unity, real reconciliation, an compassionate justice $^{30}$ - as the crucial role in Calvin's thought, including his discussion of freedom, of the weak, the poor, the suffering, of widows and exiles reminds us. (Smit 2009b:140)

\section{Conclusion}

The Reformed tradition is a living tradition. Because of its openness to the Word of God as well its ethos of being embedded in and transforming the culture in which it finds itself (Niebuhr 1951) - but without a central ecclesial or final confessional authority - this tradition is a hermeneutically vulnerable one. To stand in this tradition is to stand on the edge of the science and art of interpretation.

This tradition of 500 years and the more immediate struggles around this tradition in South Africa (and elsewhere) tell us that the impulses and ethos of the Protestant Reformation always had the potential to both contribute to justice and humanity, while it was at the same time drawn into ideologies that captured the Christian faith for the benefit and power of a few.

The case study above is reason to hope: The Scriptures has the power to liberate and open our eyes to see the world and other human beings as human beings carrying the image of God - even if we are blinded for a very long time. The pathos of God directed at suffering and marginalised human persons are powerfully represented in both Calvin and Barth, the key representatives of this tradition. Rereading both of them in ever new contexts will provide pointers to an engaged, but self-critical and humble Christian life, where we are freed to seek justice for others and in the social orders of the day.

Injustice and marginalisation take on new forms in the 21st century: people living with AIDS, stateless and fleeing immigrants, first peoples, those who are homeless and live under $1 \$$ a day, gay and transgender people, single mothers and vulnerable young girls, and - of crucial importance species in our fragile ecosystems that cannot speak for themselves.

As we who stand in the Reformed tradition look back with a mixture of shame, humility and gratitude, we also look forward in the firm hope that this specific branch of the broader Christian family will stay true to its roots under the

30.Note the reference to the three middle themes (unity, reconciliation and justice) of the Belhar Confession. 
graceful hand of God who always leads us back to seeing the truth a little better.

We are not our own. We are God's.

\section{Acknowledgements Competing interests}

The author declares that he has no financial or personal relationships which may have inappropriately influenced him in writing this article.

\section{References}

Barth, K., 1958, Church dogmatics IV/2, T\& T Clark, Edinburgh.

Barth, K., 1981, The Christian life, Eerdmans, Grand Rapids, MI.

Boesak, A., 1984, Black and reformed. Apartheid, liberation and the Calvinist tradition, Orbis, New York.

Botha, J. \& Naudé, P., 1998, Op pad met Belhar. Goeie nuus vir gister, vandag en more, Van Schaik, Pretoria.

Calvin, J., 1975, Institutes of the Christian religion, vols. 1 \& 2, Eerdmans, Grand Rapids, MI.

Cloete, G.D. \& Smit, D.J. (eds.), 1984, A moment of truth. The confession of the Dutch Reformed Mission Church 1982, Eerdmans, Grand Rapids, MI.

de Gruchy, J., 1991, Liberating reformed theology. A South African contribution to an ecumenical debate, Eerdmans, Grand Rapids, MI.

de Gruchy, J.W. (with Steve de Gruchy), 2004, The church struggle in South Africa SCM, London.

Hansen, L. (red.), 2013, Opstelle oor Gereformeerd- wees vandag. Versamelde opstelle 4, Sun Press, Stellenbosch.

Müller, B.A., Burger, C.W. \& en Smit, D.J. (reds.), 1991, Riglyne vir prediking oor die wandel met God. Woord teen die lig IIII/2, NGKU, Kaapstad.

Naudé, P., 2009, 'The two faces of Calvin in South Africa: In honour of the 500th commemoration of John Calvin's birth', Nederduits Gereformeerde Teologiese Tydskrif 30(3 \& 4), 607-613, 614-619.

Naudé, P., 2011, Neither calendar nor clock. Perspectives on the Belhar confession, Eerdmans, Grand Rapids, MI.

Naudé, P., 2012, 'The Belhar confession and church and society: A comparative reading in five statements', Acta Theologica 32(2), 147-161.

Naudé, P., 2013, 'The reception of Karl Barth in South Africa 1960-1990 - Selected perspectives', in M.-A. Plaatjies-Van Huffel \& R. Volsoo (eds.), Reformed churches in South Africa and the struggle for justice. Remembering 1960-1990, pp. 186-199, Sun Press, Stellenbosch.

Ned Geref Kerk, 1974, Ras, volk en nasie. Volkereverhoudings in die lig van die Skrif, NGKU, Pretoria.
Ned Geref Kerk, 1986, Kerk en samelewing, Pro Christo, Bloemfontein.

Niebuhr, H.R., 1951, Christ and culture, Harper and Row, New York.

Smit, D.J., 1984a, 'In a special way the God of the destitute, the poor, and the wronged', in D.G. Cloete \& D.J. Smit (eds.), A moment of truth, pp. 53-65, Eerdmans, Grand Rapids, MI.

Smit, D.J., 1992, 'Reformed theology in South Africa: A story of many stories', Acto Theologica 12(1), 88-110.

Smit, D.J., 1988, 'Paradigms of radical grace', in C. Villa-Vicencio (ed.), On reading Kar Barth in South Africa, pp. 17-44, Eerdmans, Grand Rapids, MI.

Smit, D.J., 1997, 'Liturgy and life? On the importance of worship for Christian ethics', Scriptura 62, 259-280. https://doi.org/10.7833/62-0-621

Smit, D.J., 2002, “'Christ transforming culture?” Nagedink oor die aard van die gereformeerde geloof', Acta Theologica 3, 125-149.

Smit, D.J., 2007a, Essays in public theology. Collected essays 1, Sun Press, Stellenbosch.

Smit, D.J., 2007b, “'...The doing of the little righteousness" - On justice in Barth's view of the Christian life', in E. Conradie (ed.), Essays in public theology. Collected essays 1, pp. 343-358, Sun Press, Stellenbosch.

Smit, D.J., 2008a, Geloof en openbare lewe. Versamelde opstelle 2, Sun Press, Stellenbosch.

Smit, D.J., 2008b, '...op ' $n$ besondere wyse die God van die noodlydende, die arme en die verontregte', in D.J. Smit (ed.), Geloof en openbare lewe, pp. 277-306, Sun Press, Stellenbosch.

Smit, D.J., 2009a, Essays on being reformed. Collected essays 3, Sun Press, Stellenbosch.

Smit, D.J., 2009b, 'Freedom in belonging? John Calvin's understanding of human freedom', in Essays on being reformed. Collected essays 3, pp. 121-140, Sun Press, Stellenbosch.

Smit, D.J., 2009c, 'On learning to see? A reformed perspective on the church and the poor', in D.J. Smit (ed.), Essays on being reformed. Collected essays 3, pp. 473-492, Sun Press, Stellenbosch.

Smit, D.J., 2009d, 'Views on Calvin's ethics from a South African perspective', in R Vosloo (ed.), Essays on being Reformed. Collected essays 3, pp. 1-34, Sun Press, Stellenbosch.

Smit, D.J., 2013a, 'Oor die Belydenis van Belhar: Ontstaan, inhoud, respesie, relevansie', in L. Hansen (ed.), Opstelle oor Gereformeerd- wees vandag, pp. 129-156, Sun Press, Stellenbosch.

Smit, D.J., 2013b, 'Oor Jakobus en die belydenis van Belhar', in L. Hansen (ed.), Opstelle oor Gereformeerd- wees vandag, pp. 211-230, Sun Press, Stellenbosch.

Smit, D.J., 2013c, 'Wat beteken "Gereformeerd?"', in L. Hansen (ed.), Opstelle oor Gereformeerd- wees vandag, pp. 21-32, Sun Press, Stellenbosch.

Smit, D.J., 2013d, 'Woord van God, Woord van die lewe', in L. Hansen (ed.), Opstelle oor Gereformeerd- wees vandag, pp. 41-64, Sun Press, Stellenbosch.

Stevenson, W.R., 1999, Sovereign grace. The place and significance of Christian freedom in John Calvin's political thought, OUP, New York.

Van Zyl, M.S., 2013, 'Prayer: The chief exercise of faith. The centrality of prayer in faith and obedience according to Karl Barth', Unpublished DTh-thesis, University of Stellenbosch, Stellenbosch.

Villa-Vicencio, C., 1988, On reading Karl Barth in South Africa, Eerdmans, Grand Rapids, Ml.

Wolterstorff, N., 1987, 'The wounds of God', The Reformed Journal 37, 14-22. 